\title{
Purification and Characterization of 6-Phosphogluconate Dehydrogenase from Japanese Quail (Coturnix, coturnix japonica) Erythrocytes
}

\author{
Herdi RAFAT BAQI ${ }^{1}$, Yusuf TEMEL ${ }^{2 *}$, Mehmet ÇİFTCi ${ }^{1}$
}

\begin{abstract}
In this study, the 6PGD enzyme from Japanese quail erythrocytes was purified with specific activity of $52.84 \mathrm{EU} / \mathrm{mg}$ and $69 \%$ yield of purification by $2^{\prime}$, $5^{\prime}$ - ADP Sepharose 4B affinity gel in a single chromatographic method. The purification folds of the enzyme were 4984 folds. The purified enzyme was checked using SDS polyacrylamide gel electrophoresis (SDS-PAGE) method; the result of gel showed a single band. The subunit molecular weight of the enzyme was calculated as $81 \mathrm{kDa}$ by the SDS-PAGE method. The characterization studies of the 6PGD enzyme from erythrocytes of Japanese quail showed: the optimum ionic strength to be at $0.5 \mathrm{M}$ Tris- $\mathrm{HCl}$, optimum and stable $\mathrm{pH}$ values to be at $0.5 \mathrm{M}$ Tris- $\mathrm{HCl}$ buffers $\mathrm{pH}$ 8.0. The optimal temperature for the enzyme activity was found at $60{ }^{\circ} \mathrm{C}$. Finally, the $\mathrm{K}_{\mathrm{M}}$ and $\mathrm{V}_{\max }$ values for the 6PGD enzyme from Japanese quail's erythrocytes were calculated respectively for the 6 PGA the $\mathrm{K}_{\mathrm{M}}$ value found as $0.120 \mathrm{mM}, \mathrm{V}_{\max }$ value as $0.191 \mathrm{EU} / \mathrm{mL}$ and for $\mathrm{NADP}^{+}$the $\mathrm{K}_{\mathrm{M}}$ value as $0.017 \mathrm{mM}$ and $\mathrm{V}_{\max }$ value as $0.228 \mathrm{EU} / \mathrm{mL}$.
\end{abstract}

Key words: Quail, 6PGD, erythrocytes, purification, characterization.

\section{6-Fosfoglukonat Dehidrogenaz Enziminin Japon Bıldırcın (Coturnix Coturnix Japonica) Eritrositlerinden Saflaştırılması ve Karakterizasyonu}

ÖZET: Bu çalışmada Japon bıldırcın eritrosit dokularından 6-fosfoglukonat dehidrogenaz enzimi (6PGD) 52,84 EU.mg ${ }^{-1}$ spesifik aktiviteyle ve \% 69 verimle 2', 5'-ADP Sepharose 4B afinite kromatografisi kullanılarak saflaştırıldı. Japon bıldırcın eritrositlerinden saflaştırılan 6PGD enzimi için saflaştırma katsayısı 4984 olarak bulundu. Enzim saflığının kontrolü için SDS-poliakrilamid jel elektroforezi (SDS-PAGE) yapıldı ve tek bant gözlendi. SDS-PAGE yöntemi kullanılarak enzimin alt birimlerinin molekül kutlesi $81 \mathrm{kDa}$ olarak hesaplandı. Optimum iyonik şiddet $0,5 \mathrm{M}$ Tris-HCl, optimum $\mathrm{pH}$ ve stabil $\mathrm{pH}$ 0,5 M Tris-HCl tamponu $\mathrm{pH} 8,0$ olarak bulundu. Optimum sicaklık $60{ }^{\circ} \mathrm{C}$ olarak bulundu. Ayrica Japon bildırcın 6PGD enziminin $\mathrm{K}_{\mathrm{M}}$ ve $\mathrm{V}_{\max }$ değerleri Lineweaver-Burk grafiklerinden sırasıyla 6PGA substratı için $\mathrm{K}_{\mathrm{M}}$ değeri 0,120 mM, $\mathrm{V}_{\max }$ değeri 0,191 EU/mL, NADP ${ }^{+}$substratı için $\mathrm{K}_{\mathrm{M}}$ değeri $0,017 \mathrm{mM}, \mathrm{V}_{\max }$ değerise $0,228 \mathrm{EU} / \mathrm{mL}$ olarak hesapland1.

Anahtar kelimeler: Bıldırcın, 6PGD, eritrosit, saflaştırma, karakterizasyon.

\footnotetext{
${ }^{1}$ Herdi RAFAT BAQI ${ }^{1}$ (Orcid ID: 0000-0002-1134-1076), Mehmet ÇİFTCİ ${ }^{1}$ (Orcid ID: 0000-0003-4971-4242), Bingol University, Faculty of Sciences and Arts, Department of Chemistry, Bingol, Turkey.

2 Yusuf TEMEL (Orcid ID: 0000-0001-8148-3718 ), Bingol University, Vocational Schools, Department of Health Services, Bingol, Turkey

*Sorumlu Yazar/Corresponding Author: Yusuf TEMEL, e-mail: ytemel@bingol.edu.tr

* This study was produced from Hardi RAFAT BAQI's Master's thesis.

Article was orally presented at 8th International Advanced Technologies Symposium, Firat University, Elazig-Turkey (IATS 2017) symposium. 


\section{INTRODUCTION}

6-Phosphogluconate Dehydrogenase (6PGD) enzyme commission number E.C 1.1.1.44 is the third enzyme of the pentose phosphate pathway. It is responsible for the conversion of 6phosphogluconic acid 6PGA to D-ribulose 5-phosphate and $\mathrm{CO}_{2}$ with existing of $\mathrm{NADP}^{+}$coenzyme (Beydemir et al. 2004). The enzyme is located in the cytoplasm of all living cells, including microorganisms, plants and animal cells (Toews et al., 1976).

Pentose phosphate pathway (PPP) (Figure 1), takes place in the cytoplasm of the cells since the enzymes in which catalyze the reactions of the PPP process are cytosolic enzymes. Here in PPP NADP ${ }^{+}$ is used for dehydrogenation as the hydrogen atom acceptor. The reactions in this pathway are divided into two phases (irreversible oxidative phase, reversible non oxidative phase). First phase is the phase of dehydrogenation and decarboxylation of glucose 6-phosphate that yields a pentose sugar (ribulose 5phosphate). Second phase is converting of ribulose 5-phosphate to glucose 6-phosphate by a series of reactions catalyzed by (trans ketolase and trans aldolase) enzymes (Murray et al., 2003).

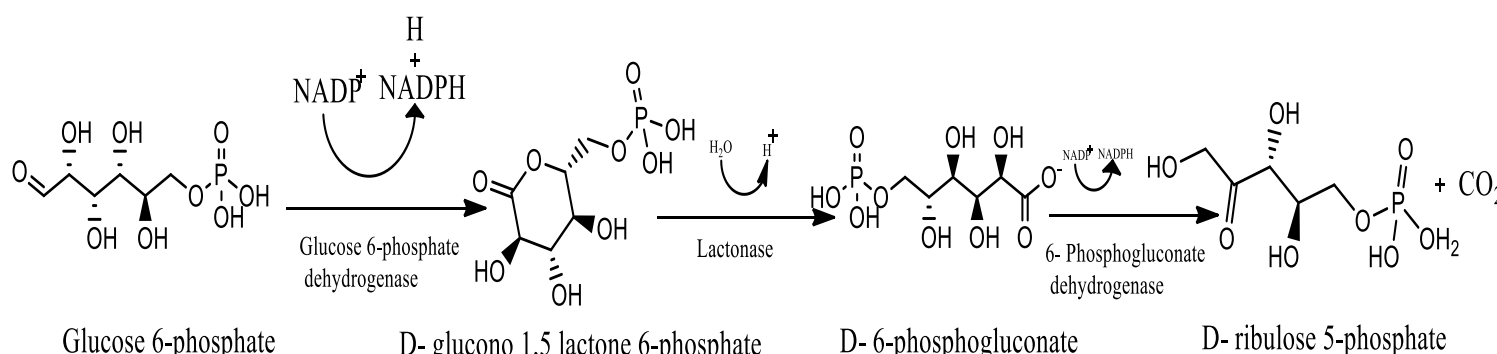

Figure 1: 6PGD enzyme catalyzing reaction

In the enzyme's reaction, NADPH is also produced. It has the function of protecting cells against oxidizing agents by producing the reduced glutathione GSH (Bianchi et al. 2001; Nelson and Cox 2005). Besides that, NADPH plays a role in producing of many biomolecules as fatty acids, steroids and some amino acids (Human et al. 1983; Srivastava and Beutler 1970). Due to its functions 6PGD could be called as an antioxidant enzyme. In cases enzyme's deficiency, the production levels of NADPH would be less than normal. In some cases no NADPH productions would be observed at all. This condition causes an increase of the erythrocyte's sensitivity towards the activity of the hemolytic oxidative agents and leads to damaging of the cells. The enzyme's kinetic properties, its role in the pentose phosphate pathway, regulations of the enzyme, genetics and the enzyme's role for the production of fatty acids had been studied for long time (Zera et al., 2014). The 6PGD enzyme from the prokaryotic and eukaryotic microorganisms sequenced, the result showed it had 468 amino acids. The arrangement of the protein amino acids is almost similar in the prokaryotic and eukaryotic microorganisms, reversibly the bovine 6PGD that comprises of 466 amino acids shows the central region on the protein to be alike of those of bacterial enzyme but different at the protein C- and N-terminals (Reizer et al. 1991). The sequences of the amino acids for 6PGD enzymes from about 40 various sources had been reported containing pig (Harbitz et al., 1990), Bacillus subtilis (Fujita and Fujita, 1987), sheep (Carnes and Walker, 1983), human (Kwok et al., 1996) and Escherichia coli (Nasoff et al. 1984). The three-dimensional enzyme structure for sheep's liver enzyme is the only one that was determined at a resolution of $2.5 \mathrm{~A}^{\circ}$ (Adams et al., 1983). The sequencing results for the 6PGD enzyme from 37 various sources showed that the highest important regions of the enzyme's structure like the active site, in which the enzymes functions of binding to the substrates and coenzymes are happen, is located in conserved regions in the enzyme's 
structure. In addition some other regions of the enzymes structures from all different species showed a big similarity in their locations (Goulielmos et al., 2004). The aim of the study was purification and characterization of 6- phosphogluconate dehydrogenase enzyme from quail erythrocyte.

\section{EXPERIMENTALS AND METHODS}

\section{Chemicals}

The chemicals used for conducting all the experiments throughout this study were all analytical graded from Sigma, Merck, Fishcer Scientific, ChemSolute bio and Applichem and they are listed as follows:

From Sigma: ammonium sulfate, magnesium chloride, sodium chloride, sodium bicarbonate, sodium hydroxide, potassium phosphate, potassium chloride, EDTA ethylene diamine tetra acetic acid, Tris (trihydroxy methyl amino methane), isopropanol, $\beta$-mercaptoethanol, acrylamide, TEMED (N, N, $\mathrm{N}, \mathrm{N}$ tetramethylethylenediamine), silver nitrate, hydrochloric acid, phosphoric acid, glycerine, ethanol, methanol, acetic acid, bovine serum albumin, 6PGA (6-phosphogluconate monosodium salt), 2', 5 '-ADP Sepharose 4B. From Merck: potassium acetate, bromothymol blue, sodium acetate, potassium hydroxide, glycine amino acid and trichloroacetic acid. From Fishcer Scientific: SDS (sodium dodecyl sulfate), Commasie Brilliant Blue G-250, Brilliant Blue R-250 electrophoresis grade. From the Applichem: NADP ${ }^{+}$and from the ChemSolute Bio: ammonium persulfate.

\section{Sample collection and preparing the hemolysate}

Blood samples of the Japanese quail were obtained using decapitation method from the agriculture faculty's research farm of the Bingol University. Blood samples were kept at $4{ }^{\circ} \mathrm{C}$ and transferred to the laboratory within EDTA containing tubes. In order to distinguish the erythrocyte from the plasma, blood samples were filtered to remove any impurities and equally distributed into eppendorf tubes then centrifuged at $2500 \mathrm{rpm}$ at $4{ }^{\circ} \mathrm{C}$ for 15 minutes. The plasma and leukocytes were removed using a dropper then the precipitated erythrocytes washed for three times by $0.16 \mathrm{M} \mathrm{KCl}$ solution and each time the solution centrifuged for 15 minutes at $2500 \mathrm{rpm}$ at $4^{\circ} \mathrm{C}$. Later in order to obtain the hemolysate, the RBCs were hemolyzed by using 1:5 volume of ice water, the hemolysate solution was mixed well to ensure the cell membrane decomposition. Then, for the removal of the cell debris in the hemolysate, the blood was centrifuged for 30 minutes at $4^{\circ} \mathrm{C}$ using a speed of $10000 \mathrm{~g}$. After the centrifugation completed, the supernatant was isolated from the precipitate and used for further enzyme purification processes that include the quantitative protein determinations and loading the hemolysate to the $2^{\prime}, 5^{\prime}$ ADP Sepharose 4B affinity gel chromatography column (Ninfali et al., 1990).

\section{2', 5 '-ADP Sepharose 4B affinity gel chromatography}

For preparing the affinity gel, $2 \mathrm{~g}$ of solid 2', 5'-ADP Sepharose 4B were poured into a $10 \mathrm{~mL}$ $(1 \times 10 \mathrm{~cm})$ volume tube, the substance washed repeatedly using $400 \mathrm{~mL}$ of distilled water (D.W) for removing any foreign materials in the gel if existed; during the washing process, the gel swelled up. The air bubbles removed inside the swelled gel by water trompe using a balancing homogenizing buffer $(0.1$ $\mathrm{M}$ potassium acetate/ $0.1 \mathrm{M}$ potassium phosphate $\mathrm{pH}$ 6.0). By the end of this process, the suspension of the gel was accomplished in $1 \times 10 \mathrm{~cm}$ closed column system where the gel packed. In the next step, the packed gel was washed using a balancing buffer and the flow rate controlled by a peristatic pump. The washing process done by using a setting of $20 \mathrm{~mL}^{\text {. Hour }}{ }^{-1}$ of the peristatic pump (Ninfali et al. 1990). After the column was homogenized with the ( $\mathrm{pH}$ 7.3) balancing buffer, the column would be ready for using. The prepared hemolysate from previous step loaded into the affinity column then washed repeatedly and respectively with $25 \mathrm{~mL}$ volume portions of $0.1 \mathrm{M}$ potassium acetate/ $0.1 \mathrm{M}$ potassium 
phosphate ( $\mathrm{pH} 7.3$ ). Then $25 \mathrm{~mL}$ of $0.1 \mathrm{M} \mathrm{KCl} / 0.1 \mathrm{M}$ potassium phosphate $\mathrm{pH} 7.85$ the flow rate set up fixed at $20 \mathrm{~mL} /$ hour by using the peristatic pump and temperature kept at $4{ }^{\circ} \mathrm{C}$. After removing all of the unwanted debris and proteins, elution buffer containing $80 \mathrm{mM}$ potassium phosphate/ $80 \mathrm{mM} \mathrm{KCl}+$ $5 \mathrm{mM} \mathrm{NADP}^{+}$and $10 \mathrm{mM}$ EDTA pH 7.3, used to elute out the attached 6PGD enzyme from the gel in the column. The eluate should be collected in fractions using labeled Eppendorf tubes, and each fraction should be tested for the enzyme's activity (Ninfali et al., 1990; Morelli et al., 1978).

\section{Measurement of 6PGD enzyme activity:}

The enzyme's activity measured spectrophotometrically at $25^{\circ} \mathrm{C}$ using Beutler's method. In this method the absorbance of reduction of $\mathrm{NADP}^{+}$to NADPH was measured depending on time at $340 \mathrm{~nm}$.

\section{Qualitative determination of proteins}

The eluted fractions from the affinity column were tested for existence of proteins qualitatively. The absorbances of fractions were measured against the elution buffer as blank at $280 \mathrm{~nm}$ which is the maximum wavelength $(\lambda \max )$ for tryptophan, phenyl alanine and tyrosin (Segel, 1968).

\section{Quantitative determination of protein}

The Bradford assay protocol was used for quantitative determination of proteins, BSA was used as a standard (Bradford, 1976).

\section{SDS-PAGE}

The eluted 6PGD enzyme from the affinity column checked for determining of its purity using sodium dodecyl sulfate polyacrylamide gel electrophoresis. $0.1 \%$ SDS containing $3 \%$ and $10 \%$ of acrylamide and bisacrylamide respectively were used in stacking gel and separation gels. The molecular weight of the 6PGD enzyme purified was determined by SDS-PAGE (Laemmli, 1970).

\section{Determination of the optimum pH}

The $\mathrm{pH}$ value which the enzyme has its maximum activity at is assigned as the optimum $\mathrm{pH}$ value for the 6PGD enzyme activity. Different buffers with different ranges of $\mathrm{pH}$ values used. First is TrisHCl buffer, $0.5 \mathrm{M} \mathrm{pH}$ ranges of 7.0 - 9.0. Second buffer is potassium phosphate $1 \mathrm{M}, \mathrm{pH}$ ranges from 5.5 -7.5 and 8.0 .

\section{Determination of the stable $\mathbf{p H}$}

Two buffers $0.5 \mathrm{M}$ Tris- $\mathrm{HCl}$ and $1 \mathrm{M}$ potassium phosphate were used for determining the stable $\mathrm{pH}$ value; the Tris- $\mathrm{HCl}$ buffer $\mathrm{pH}$ ranged from $7.0-9.0$ and $\mathrm{pH}$ range of potassium phosphate buffer was from 5.5 to 8.0 .

\section{Determination of the optimum ionic strength}

For determining the effect of ionic strength on the 6PGD enzyme, different series concentrations of Tris- $\mathrm{HCl}$ buffer $(10 \mathrm{mM}-1000 \mathrm{mM})$ used in order to determine the maximum activity of the 6PGD enzyme.

\section{Determining the optimum temperature}

In order to determine the optimum temperature for the maximum enzyme's activity, the enzyme assayed using $0.5 \mathrm{M}$, Tris- $\mathrm{HCl}$ buffer $\mathrm{pH} 8.0$ at different ranges of temperatures $\left(0{ }^{\circ} \mathrm{C}\right.$ to $\left.70{ }^{\circ} \mathrm{C}\right)$. The temperature at which the enzyme gave its maximum activity assigned as the optimum temperature for the enzyme. 


\section{Kinetic studies}

For determining the $\mathrm{K}_{\mathrm{M}}$ and $\mathrm{V}_{\max }$ values of the substrate and coenzyme (6PGA and $\mathrm{NADP}^{+}$) of the 6PGD enzyme, a method contained of using stable concentrations of $\mathrm{NADP}^{+}$with 8 different concentrations of 6PGA $(100 \mathrm{mM}, 200 \mathrm{mM}, 300 \mathrm{mM}, 400 \mathrm{mM}$ and $500 \mathrm{mM})$ for finding the 6PGAs ( $\mathrm{K}_{\mathrm{M}}$ and $\mathrm{V}_{\max }$ ), and likewise, for $\mathrm{NADP}^{+}$coenzyme, stable concentrations of 6PGA used in the enzyme's assay with 8 different concentration of the $\mathrm{NADP}^{+}(20 \mathrm{mM}, 40 \mathrm{mM}, 66 \mathrm{mM}, 75 \mathrm{mM}, 100 \mathrm{mM})$ coenzyme solution for finding the $\mathrm{NADP}^{+} \mathrm{s}\left(\mathrm{K}_{\mathrm{M}}\right.$ and $\left.\mathrm{V}_{\mathrm{max}}\right)$ values. The data collected from these measurements used for plotting of the Lineweaver-Burk graphs for both $\mathrm{NADP}^{+}$and 6PGA in which the values for $\mathrm{K}_{\mathrm{M}}$ and $\mathrm{V}_{\max }$ were found by calculations in order to indicate the affinity of the 6PGD enzyme towards the two substrate and coenzyme.

\section{RESULTS AND DISCUSSIONS}

In this study, 6PGD enzyme was purified and characterized in quail erythrocytes. (Coturnix coturnix japonica) erythrocytes for the first time. Different methods were used for the purification of 6PGD enzyme throughout the literature of enzymology like DEAE cellulose; CM-cellulose ions exchange chromatography (Villet and Dalziel, 1969), DEAE Sephadex, hydroxy apatite (Silverberg and Dalziel, 1973), $\mathrm{NADP}^{+}$Sepharose, $\mathrm{NADP}^{+}$agarose (Betts and Mayer, 1975), matrix gel-A column chromatography (Somers et al. 1991), DEAE Sephadex A-50 ion-exchange chromatography (Demir et al., 2003), 2', 5'-ADP-sepharose 4B affinity gel (Altıkat et al., 2002; Akyüz et al., 2003; Bayındır et al., 2018; Akkoyun et al., 2018). The method used for the purification of the enzyme was 2', 5'-ADP Sepharose 4B affinity gel chromatography, which is a very powerful, reliable, easy, economic and a single step purification method that gives very good purification yields with an ability to purify bulk amounts of the enzymes (Temel et al., 2017a,b; Temel and Kocyigit, 2017). These advantages of the method are some of the characteristics of it which make it by comparison to other purification methods to purify different enzymes (Temel et al., 2018; Temel and Bayındır, 2019).

The SDS-PAGE experiment was conducted for checking of the purity and the determining of molecular weights of the purified enzyme that eluted from the affinity column, the results of the test showed a single band protein on the gel for two of the eluates that had the maximum activity of the $6 \mathrm{PGD}$ in them. This proved the existence of only one type of protein in the eluate fraction which is the 6PGD enzyme from the Japanese quail erythrocytes (Figure 2).

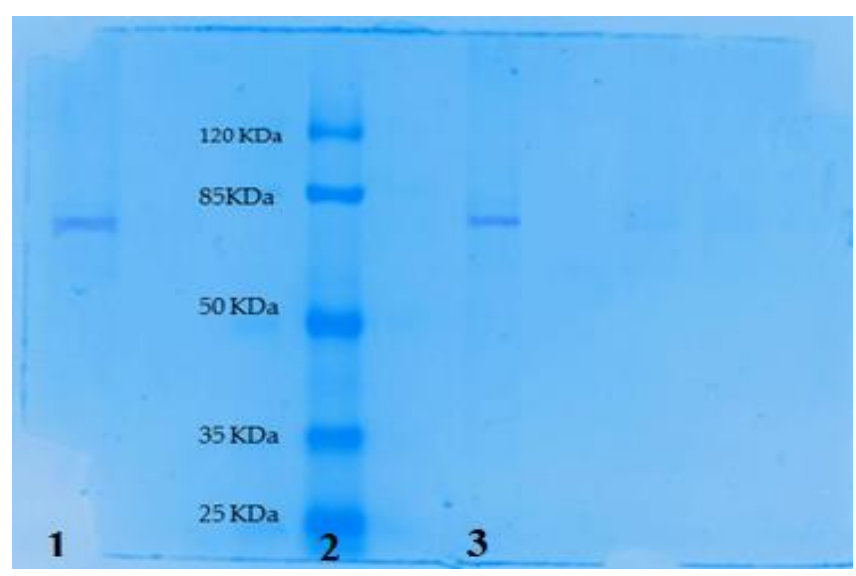

Figure 2. The SDS-PAGE photograph for the 6PGD Japanese quail's erythrocytes enzyme: the $120 \mathrm{kDa}$ protein is $\beta$ galactosidase from E. coli, $85 \mathrm{kDa}$ protein is bovine serum albumin from bovine plasma, $50 \mathrm{kDa}$ protein is the egg white ovalbomin, the $35 \mathrm{kDa}$ protein is carbonic anhydrase protein from human erythrocytes and $29 \mathrm{kDa}$ standard protein is CA from cattle's erythrocytes in line 2 . The $81 \mathrm{kDa}$ protein in lane 1 and 3 is the 6-phosphogluconate dehydrogenase enzyme protein from Japanese quail's erythrocytes. 
The quality and efficiency of the purification method was calculated using the Bradford's method (Bradford 1976). The amount of proteins, volumes and activities in the hemolysate and purified enzyme samples were used for calculation of the purification and the resulted purified enzyme solution. The purification result shows $69 \%$ yields of purification, 4984 fold purification of the proteins, and the specific activity of 52.84 EU. $\mathrm{mg}^{-1}$ for the purified 6PGD enzyme (Table 1).

Table 1. The information about purification of the 6PGD Japanese quail's erythrocytes enzyme using $2^{\prime}, 5^{\prime}$-ADP Sepharose 4B affinity gel chromatography

\begin{tabular}{|c|c|c|c|c|c|c|c|c|}
\hline Sample & $\begin{array}{c}\text { Volume } \\
(\mathbf{m L})\end{array}$ & $\begin{array}{l}\text { Protein } \\
\left(\mathbf{m g} \cdot \mathbf{m L}^{-1}\right)\end{array}$ & $\begin{array}{c}\text { Total protein } \\
\text { (mg) }\end{array}$ & $\begin{array}{c}\text { Activity } \\
\left(\text { EU.mL }{ }^{-1}\right)\end{array}$ & $\begin{array}{c}\text { Total } \\
\text { activity }(\mathbf{E U})\end{array}$ & $\begin{array}{l}\text { Specific activity } \\
\quad(\text { EU.mg } \\
\end{array}$ & $\begin{array}{c}\text { Yield } \\
\%\end{array}$ & $\begin{array}{c}\text { Purification } \\
\text { folds }\end{array}$ \\
\hline Hemolysate & 25 & 8.097 & 202.425 & 0.086 & 2.15 & 0.0106 & 100 & 1 \\
\hline $\begin{array}{c}2 \text { ', } 5 \text { '-ADP } \\
\text { Sepharose 4B } \\
\text { affinity } \\
\text { column }\end{array}$ & 5 & 0.00562 & 0.02812 & 0.297 & 1.485 & 52.84 & 69 & 4984 \\
\hline
\end{tabular}

6PGD enzyme had been investigated in many different sources and checked for its kinetic properties and characterized for its functions. The enzyme had been purified from sheep's liver (Villet and Dalziel, 1972), parsley's leaves (Demir et al., 2003), chicken's liver (Erat, 2005), rat's small intestine (Ceyhan et al., 2005), Van's cat erythrocytes (Kiliç, 2007), human's erythrocytes (Özabacigil, 2005), human cerebral (Weisz et al., 1985), rabbit mammary glands (Betts and Mayer, 1975) and rat heart and lung tissues (Adem, 2010). The enzyme's molecular weight was determined by SDS-PAGE method described previously. The molecular weight of the subunit of the purified enzyme found to be $\sim 81 \mathrm{kDa}$. The molecular weights of 6PGD enzymes from different sources in literature had been $59.5 \mathrm{kDa}$ from the rat's erythrocytes (Beydemir et al., 2004), $52.6 \mathrm{kDa}$ from Van's cat erythrocyte (Kiliç, 2007), 52 $\mathrm{kDa}$ from rat's small intestine (Ceyhan et al., 2005), E. coli bacteria had $53 \mathrm{kDa}$ 6PGD (Wang and Zhang, 2009), $118.34 \mathrm{kDa}$ from rainbow trout by gel filtration chromatography (Taranci, 2011) and 24.1 $\mathrm{kDa}$ from parsley (Demir et al., 2003). By looking through above molecular weights from different sources, we find that the molecular weight of 6PGD enzyme from Japanese quail's is different from all the mentioned sources.

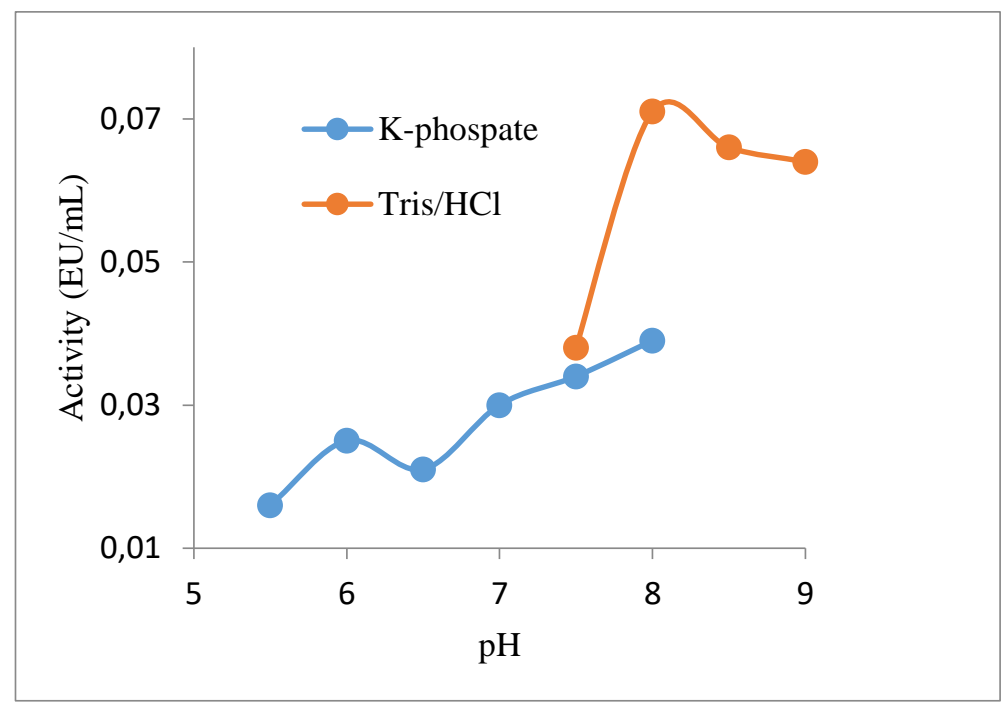

Figure 3. The optimum pH value test of the 6PGD enzyme activity from japanese quail erythrocytes 
The optimal pH value test for the quail's 6PGD enzyme activity was performed using two different buffer solutions $0.5 \mathrm{M}$ Tris- $\mathrm{HCl}$ buffer and $1 \mathrm{M}$ potassium phosphate buffer as described before. The results showed that the optimum $\mathrm{pH}$ value for the enzyme's activity was at $\mathrm{pH} 8.0$, in Tris- $\mathrm{HCl}$ buffer (Figure 3).

The effect of ionic strength on the enzyme activity was tested as described previously. The optimum ionic strength was determined at $\mathrm{pH} 8.0$, in the $500 \mathrm{mM}$ Tris- $\mathrm{HCl}$, buffer (Figure 4).

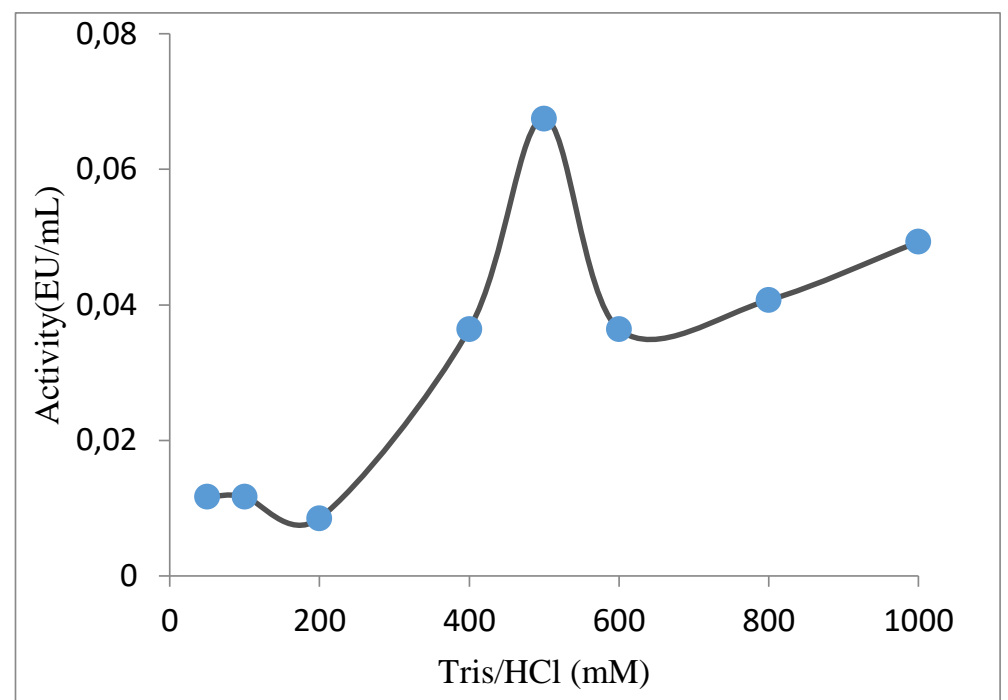

Figure 4. The optimum ionic strength effect on 6PGD Japanese quail's erythrocyte enzyme

The optimal temperature test for the enzyme's activity conducted as described in before, an increase in the activity of the enzyme was observed due to the elevating temperatures. The activity increased until $60^{\circ} \mathrm{C}$ where the enzyme had its maximum activity. However, the enzyme lost its activity when the temperature elevated more than $60^{\circ} \mathrm{C}$ due to the denaturation of the enzyme's protein structure by the effect of heat (Figure 5).

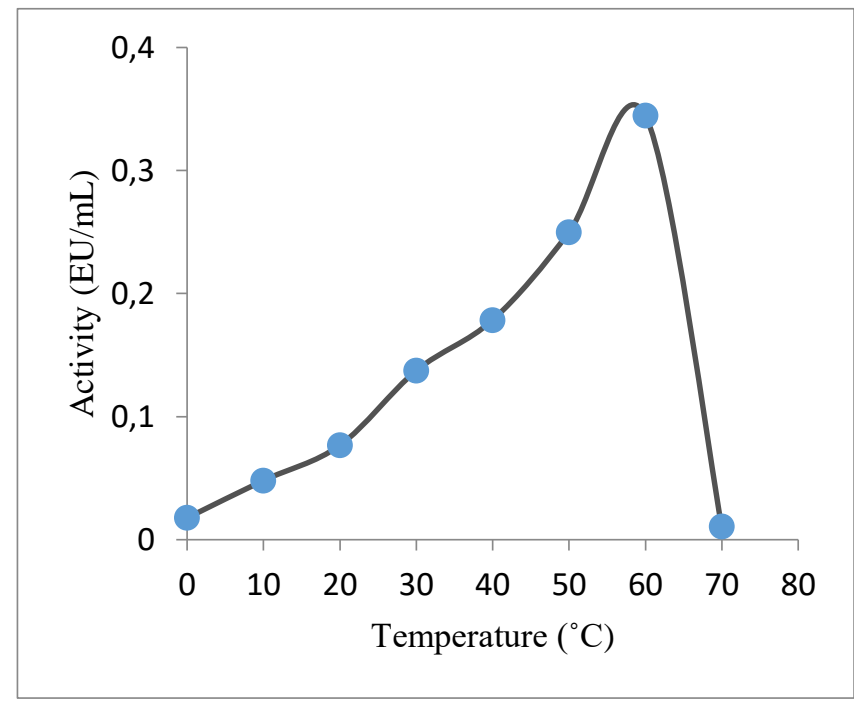

Figure 5. The effect of elevating temperatures on the 6PGD Japanese quail's enzyme activity.

The enzyme's stability tested against time and storage conditions in acidic/basic mediums as described before. The samples were assayed twice a day. The most suitable buffer solution that mostly kept the activity of the 6PGD enzyme of Japanese quail was $0.5 \mathrm{M}$ Tris- $\mathrm{HCl} \mathrm{pH} 8.0$ buffer. The enzyme 
maintained its activity for highest levels along seven days of measurements in the buffer. However, the most suitable $\mathrm{pH}$ value of the stored 6PGD enzyme in the potassium phosphate buffer was at $\mathrm{pH} 7.5$ (Figure 6a,b).
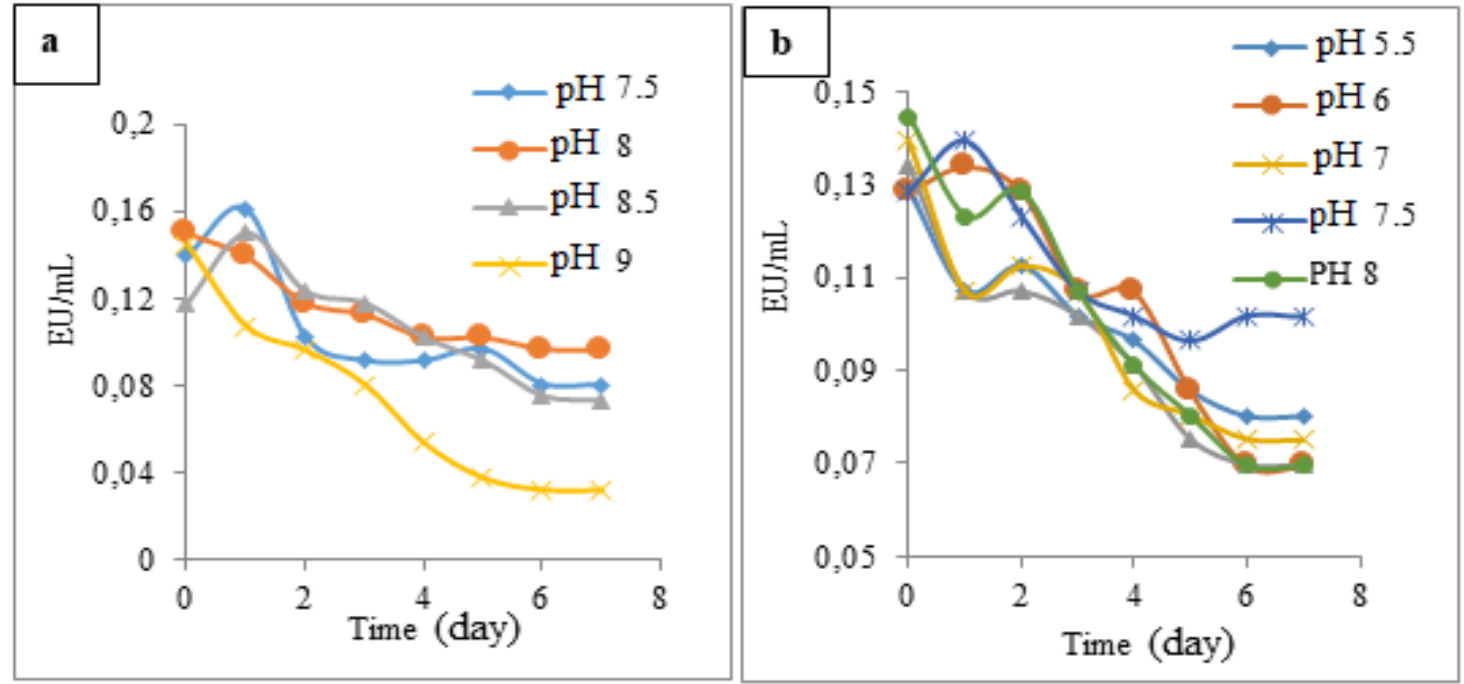

Figure 6a. The stability of the 6PGD Japanese quail's erythrocyte enzyme in Tris-HCl buffer over seven days time. b. The stability of the 6PGD Japanese quail's erythrocytes enzyme in potassium phosphate buffer over seven days time
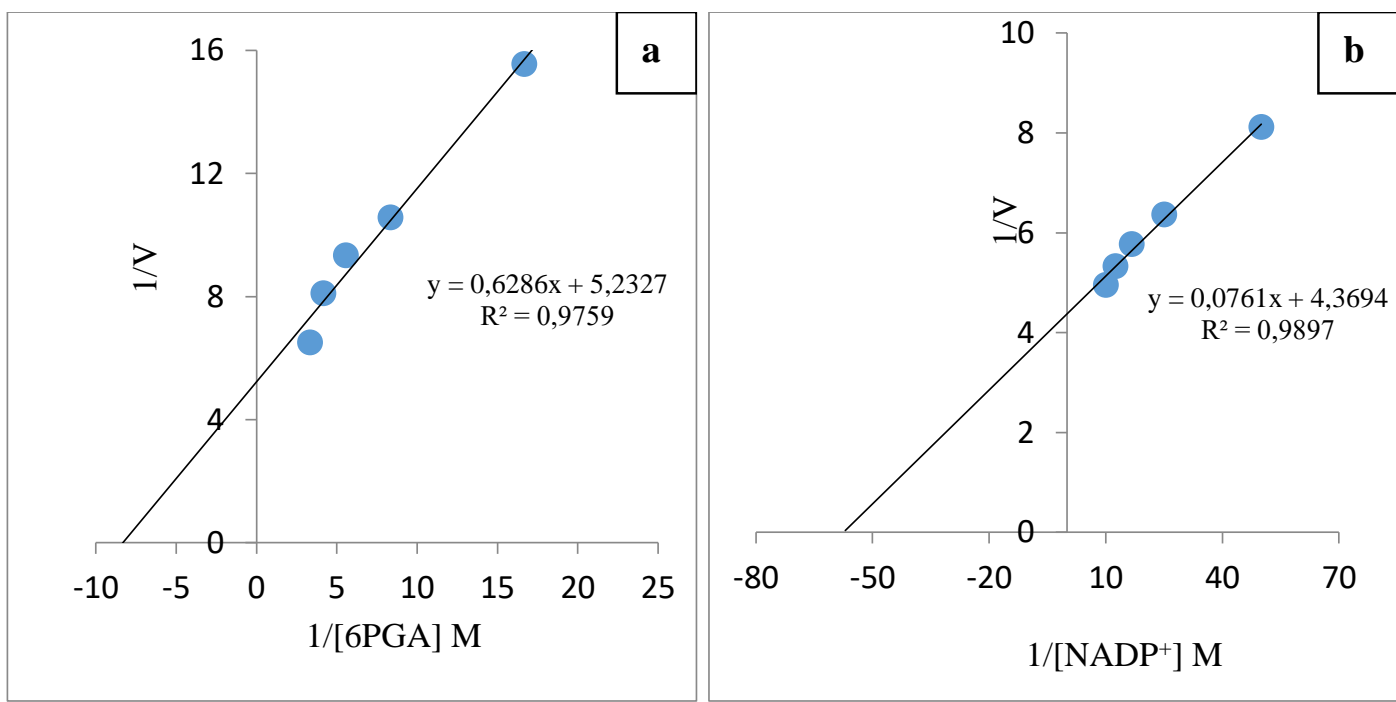

Figure 9a. The Lineweaver-Burk reciprocal plot for the 6PGA substrate: different concentrations of the 6PGA substrate for 6PGD quail's erythrocytes enzyme used in order to find the maximum velocity of the enzyme and the Michaelis- Menten constant for the substrate $\mathbf{b}$. The Lineweaver-Burk reciprocal plot for NADP ${ }^{+}$coenzyme: different concentrations of $\mathrm{NADP}^{+}$ coenzyme for 6PGD Japanese quail's erythrocytes enzyme used in order to find the maximum velocity of the enzyme and the Michaelis - Menten constant for the coenzyme.

For finding the $\mathrm{K}_{\mathrm{M}}$ and $\mathrm{V}_{\max }$ values for the enzyme substrates and coenzyme (6PGA and $\mathrm{NADP}^{+}$), at the stable concentration of the $\mathrm{NADP}^{+}$the enzyme activity was checked by using of eight different concentration of 6PGA, the collected data from the measurements used for plotting the LineweaverBurk graph between 1/V vs [1/6PGA] $\mathrm{mM}$, and the values of $\mathrm{K}_{\mathrm{M}}$ and $\mathrm{V}_{\max }$ were founded for 6PGA as $\mathrm{K}_{\mathrm{M}} 0.120 \mathrm{mM}$ and $\mathrm{V}_{\max } 0.1911 \mathrm{EU}$. $\mathrm{mL}^{-1}$. Then by using constant concentration of the 6PGA and 
different concentrations of $\mathrm{NADP}^{+}$the enzyme activity was checked as well, and the collected data from the measurements used to plot the Lineweaver-Burk graph between $1 / \mathrm{V}$ vs $\left[1 / \mathrm{NADP}^{+}\right] \mathrm{mM}$ then the $\mathrm{K}_{\mathrm{M}}$ and $\mathrm{V}_{\max }$ values calculated from the graph for $\mathrm{NADP}^{+}$as $\mathrm{K}_{\mathrm{M}} 0.0174 \mathrm{mM}$ and $\mathrm{V}_{\max } 0.2288 \mathrm{EU} . \mathrm{mL}^{-1}$. By comparing the $\mathrm{K}_{\mathrm{M}}$ values for both of the $6 \mathrm{PGA}$ and $\mathrm{NADP}^{+}$we can see that the $\mathrm{K}_{\mathrm{M}}$ value of the $\mathrm{NADP}^{+}$ is smaller than the $\mathrm{K}_{\mathrm{M}}$ value for 6PGA, which means $\mathrm{NADP}^{+}$is more favorable than 6PGA for the catalytic reactions of 6PGD enzyme of Japanese quail erythrocytes (Figure 9a,b ).

\section{CONCLUSION}

The 6-phosphogluconate dehydrogenase (6PGD) enzyme from the erythrocytes of Japanese quail (Coturnix coturnix japonica) was purified at the end of this study. The enzyme is the third enzyme of the pentose phosphate pathway (PPP) and it is considered as a secondary anti-oxidant enzyme for its role in producing the necessary NADPH that is required for removing the oxidant effects of the free radicals in the cells. The enzyme purification method was single step purification by the 2 ', 5 '-ADP Sepharose 4B affinity gel chromatography and the purified 6PGD enzyme at the end of the process was checked for its purity using the sodium dodecyl sulfate polyacrylamide gel (SDS-PAGE) method. The result was observing purely a single band on the gel which indicated that the enzyme had well-being purified and there was only one protein in the purified solution.

The purified 6PGD enzyme of the Japanese quail erythrocytes was characterized for determining its behaviors like the stable $\mathrm{pH}$ value, optimum $\mathrm{pH}$, optimum temperature value, optimum ionic strength, $\mathrm{K}_{\mathrm{M}}$ and $\mathrm{V}_{\max }$ values for the natural enzyme's substrate and its coenzyme as well as its molecular weight.

\section{ACKNOWLEDGEMENT}

Authors are indebted to Bingol University Research Project Department (BÜBAP, Project number FEF.3.16.003.) for their finical support .

\section{REFERENCES}

Adams MJ, Archibald IG, Bugg CE, Carne A, Gover S, Helliwell JR, Pickersgill RW, White SW, 1983. The three dimensional structure of sheep liver 6-phosphogluconate dehydrogenase at 2.6 A resolution. The EMBO Journal 2(6): 1009-1014.

Adem S, 2010. Siçan kalp ve akciger dokularindan glukoz-6 fosfat dehidrogenaz, 6 fosfoglukanat dehidrogenaz, glutatyon redüktaz enzimlerinin saflastirilmasi, karakterizasyonu, kotinin ve bazi ilaçlarin enzimlerin aktiviteleri üzerine etkilerinin incelenmesi. PhD thesis, Atatürk University, Institute of science.

Akkoyun MB, Bengü AŞ, Temel Y, Akkoyun HT, Ekin S, Ciftci M, 2018. The effect of astaxanthin and cadmium on rat erythrocyte G6PD, 6PGD, GR, and TrxR enzymes activities in vivo and on rat erythrocyte 6PGD enzyme activity in vitro. Journal of biochemical and molecular toxicology, 32(8), e22170.

Akyüz M, Erat M, Çiftçi M, Gümüştekin K, Bakan N, 2004. Effects of some antibiotics on human erythrocyte 6phosphogluconate dehydrogenase: an in vitro and in vivo study. Journal of enzyme inhibition and medicinal chemistry, 19(4): 361-365.

Altikat S, Çiftci M, Buyukokuroglu ME, 2002. "In vitro effects of some anesthetic drugs on enzymatic activity of human red blood cell glucose 6-phosphate dehydrogenase." Polish journal of pharmacology 54(1): 67-72.

Bayindir S, Ayna A, Temel Y, Ciftci M, 2018. The synthesis of new oxindoles as analogs of natural product 3,3bis(indolyl)oxindole and in vitro evaluation of the enzyme activity of G6PD and 6PGD. Turkish Journal of Chemistry. 42(2): 332-345.

Betts SA, Mayer RJ, 1975. Purification and properties of 6-phosphogluconate dehydrogenase from rabbit mammary $\begin{array}{llll}\text { gland. The } & \text { Biochemical 263-270. }\end{array}$ http://www.pubmedcentral.nih.gov/articlerender.fcgi?artid=1172355\&tool=pmcentrez\&rendertype=abstract.

Beutler E, 1971. Red cell metabolism manual of biochemical methods. London Academic Press: 19-68. 

japonica) Erythrocytes

Beydemir S, Ciftci M, Yilmaz H, Kufrevioglu OI, 2004. 6-phosphogluconate dehydrogenase: purification, characterization and kinetic properties from rat erythrocytes. Turkish Journal of Veterinary and Animal Science 28: 707-714. http://mistug.tubitak.gov.tr/bdyim/abs.php?dergi=vet\&amp;rak=0212-4.

Bianchi D, Bertrand O, Haupt K, Coello N, 2001. Effect of gluconic acid as a secondary carbon source on non-growing 1-lysine producers cells of corynebacterium glutamicum. purification and properties of 6-phosphogluconate dehydrogenase. Enzyme and Microbial Technology 28(9-10): 754-759. doi:10.1016/S0141-0229(01)00310-6.

Bradford MM, 1976. A Rapid and sensitive method for the quantitation of microgram quantities of protein utilizing the principle of protein-dye binding. Analytical Biochemistry 72(1-2): 248-254. doi:10.1016/0003-2697(76)905273.

Carnes A, Walker JE, 1983. Amino acid sequence of ovine 6-phosphogluconate dehydrogenase. Journal of Biological Chemistry 258(21): 12895-12906.

Ceyhan D, Danişan A, Oğüş IH, Ozer N, 2005. Purification and kinetic properties of 6-phosphogluconate dehydrogenase from rat small intestine. The Protein Journal 24(5): 293-301. doi:10.1007/s 10930-005-6750-z.

Demir H, Çiftçi M, Küfrevioğlu Öİ, 2003. Purification of 6-phosphogluconate dehydrogenase from parsley (petroselinum hortense) leaves and investigation of some kinetic properties. Preparative Biochemistry and Biotechnology 33(1): 39-52. doi:10.1081/PB-120018368.

Erat M, 2005. Purification of 6-phosphogluconate dehydrogenase from chicken liver and investigation of some kinetic properties. Preparative Biochemistry and Biotechnology 35(1): 53-69. doi:10.1081/PB-200041446.

Fujita Y, Fujita T, 1987. The gluconate operon gnt of bacillus subtilis encodes its own transcriptional negative regulator. Proceedings of the National Academy of Sciences of the United States of America 84(July): 4524-4528. doi:10.1073/pnas.84.13.4524.

Goulielmos GN, Eliopoulos E, Loukas M, Tsakas S, 2004. Functional constraints of 6-phosphogluconate dehydrogenase (6-pgd) based on sequence and structural information. Journal of Molecular Evolution 59(3): 358-71. doi:10.1007/s00239-004-2630-y.

Harbitz I, Chowdhary B, Chowdhary R, Kran S, Frengen E, Gustavsson I, Davies W, 1990. Isolation, characterization and chromosomal assignment of a partial cdna for porcine 6-phosphogluconate dehydrogenase. Hereditas 112(1): $\quad$ 83-88. https://www.scopus.com/inward/record.uri?eid=2-s2.00025295377\&partnerID=40\&md5=2544cf498948e719ae6880b6c889628a.

Human M, Kahlers SG, Kirkman HN, 1983. Intracellular glucose-6-phosphate dehydrogenase does not monomerize in human erythrocytes. Journal of Biological Chemistry 11:717-18.

Kiliç S, 2007. Van kedisi'nden 6 fosfoglukanat dehidrogenaz enziminin saflastirilmasi karekterizasyonu , kinetigi,inhibisyonu ve hplc ile tayin yöntenteminin gelistirilmesi. PhD thesis, Yüzüncü Yil University, chemistry department.

Kwok S, Tsui W, Yuet J, Chan W, Miu M, Waye Y, Fung KP, Lee CY, 1996. Identification of a cDNA encoding 6phosphogluconate dehydrogenase from a human heart cdna library 1. Biochemical Genetics 34: 365-73.

Laemmli UK, 1970. Cleavage of structural proteins during assembly of head of bacteriophage-T4. Nature 227: 68085,. doi:10.1038/227680a0.

Morelli A, Bennati U, Gaetani GF, De Flora A, 1979. Biochemical mechanisms of glucose-6-phosphate dehydrogenase deficiency. Proceedings of the National Academy of Sciences 75(4): 1979-1983, 1978. doi:10.1073/pnas.75.4.

Murray RK, Granner DK, Mayes PA, Rodwel. VW, 2003. Harper's Illustrated Biochemistry. McGraw-Hill Companies, New York, Twenty-sixth Edition. Vol. 16: 693. doi:10.1016/0307-4412(88)90029-5.

Nasoff MS, Baker HV, Wolf RE, 1984. DNA sequence of the Eschericia coli gene, Gnd, for 6- phosphoglueonate dehydrogenase. Gene 21(27): 253-264.

Nelson D, Cox M, 2005. Lehninger principles of biochemistry. WH. Freeman, New York, Volume 33, Fourth edition: 190-225. doi:10.1002/bmb.2005.494033010419.

Ninfali P, Orsenigo I, Baronciani L, Rapa S, 1990. Rapid purification of glucose-6-phosphate dehydrogenase from mammal's erythrocytes. Preparative Biochemistry 20(3-4): 297-309,. doi:10.1080/00327489008050202.

Özabacigil F, 2005. Insan eritrosit 6-fosfoglukanat dehidrogenaz enziminin saflastirilmasi, bazi ilaçlarin enzim aktivitesi üzerine in vitro ve tavsanlarda in vivo etkisinin incelenmesi. PhD thesis, Atatürk University, Health institute. 
Reizer A, Deutscher J, Saier MH, Reizer J, 1991. Analysis of the gluconate (gnt) operon of Bacillus subtilis. Molecular Microbiology 5(5): 1081-89.

Segel IH, 1968. Biochemical calculations. New York: 212-337.

Silverberg M, Dalziel K, 1973. Crystalline 6-phosphogluconate dehydrogenase from sheep liver. European Journal of Biochemistry 38(2): 229-38,. doi:10.1111/j.1432-1033.1973.tb03054.x.

Somers DON, Hajdu J, Adams MJ, 1991. A two-step purification procedure for sheep liver 6-phosphogluconate dehydrogenase. Protein Expression and Purification 389(2): 385-389.

Srivastava SK, Beutler E, 1970. Glutathione metabolism of the erythrocyte. the enzymic cleavage of glutathionehaemoglobin preparations by glutathione reductase. Biochemical Journal 119(3): 353-357,. http://www.biomednet.com/db/medline/71112233.

Taranci A, 2011. Purification and characterization of 6-phosphogluconate dehydrogenase (e.c. 1.1.1.44) enzyme from rainbow trout (Oncorhynchus mykiss) erythrocytes and investigation of the effects of some metals on enzyme activity. Master thesis, Ataturk University, Institute of science: 93.

Temel Y, Bayındır S, 2019. The Synthesis of Thiosemicarbazone-Based Aza-Ylides as Inhibitors of Rat Erythrocyte Glucose 6-Phosphate Dehydrogenase Enzyme. Iğdır Üniversitesi Fen Bilimleri Enstitüsü Dergisi, 9(3): 15031512 .

Temel Y, Bozkuş T, Karagözoğlu Y, Çiftçi M, 2017b. Glutatyon Redüktaz (GR) Enziminin Japon Bıldırcın (Coturnix coturnix japanica) Eritrositlerinden Saflaştırılması ve Karakterizasyonu. Iğdır Üniversitesi Fen Bilimleri Enstitüsü Dergisi, 7(3): 143-150.

Temel Y, Küfrevioğlu Öİ, Ciftci M, 2017a. Investigation of the effects of purification and characterization of turkey (Meleagris gallopavo) liver mitochondrial thioredoxin reductase enzyme and some metal ions on enzyme activity. Turkish Journal of Chemistry, 41(1): 48-60.

Temel Y, Kocyigit UM, 2017. Purification of glucose-6-phosphate dehydrogenase from rat (Rattus norvegicus) erythrocytes and inhibition effects of some metal ions on enzyme activity. Journal of biochemical and molecular toxicology, 31(9): e21927.

Temel Y, Koçyigit UM, Taysı MŞ, Gökalp F, Gürdere MB, Budak Y, Ceylan M, Gülçin İ, Çiftci M, 2018. Purification of glutathione S-transferase enzyme from quail liver tissue and inhibition effects of (3aR, 4S, 7R, 7aS)-2-(4((E)-3-(aryl) acryloyl) phenyl)-3a, 4, 7, 7a-tetrahydro-1H-4, 7-methanoisoindole-1, 3 (2H)-dione derivatives on the enzyme activity. Journal of biochemical and molecular toxicology, 32(3): e22034.

Toews ML, Kanji MI, Carpe, WR, 1976. 6-Phosphogluconate dehydrogenase. The Journal of Biochemical Chemistry 251(22): 7121-31.

Villet RH, Dalziel K, 1969. Purification and properties of sheep liver phosphofructokinase. The Biochemical Journal 113(2): 235-242,.

http://www.pubmedcentral.nih.gov/articlerender.fcgi?artid=1184628\&tool=pmcentrez\&rendertype=abstract.

Villet RH, Dalziel K, 1972. Studies of 6-phosphogluconate dehydrogenase from sheep liver: 1. kinetics of the reductive carboxylation reaction. European Journal of Biochemistry 27(2): 244-250,. doi:10.1111/j.14321033.1972.tb01833.x.

Wang Y, Zhang YHP, 2009. Overexpression and simple purification of the Thermotoga maritima 6-phosphogluconate dehydrogenase in Escherichia coli and its application for NADPH regeneration. Microbial Cell Factories 8: 30, doi:10.1186/1475-2859-8-30.

Weisz KS, Schofield PJ, Edwards MR, 1985. Human brain 6-phosphogluconate dehydrogenase: purification and kinetic properties. Journal of Neurochemistry 44 (2): 510-517.

Zera AJ, Wehrkamp C, Schilder R, Black C, Gribben P, 2014. Purification and characterization of 6-phosphogluconate dehydrogenase from the wing-polymorphic cricket, gryllus firmus, and assessment of causes of morphdifferences in enzyme activity. Comparative Biochemistry and Physiology Part - B: Biochemistry and Molecular Biology 172-173(1): Elsevier Inc. 29-38,. doi:10.1016/j.cbpb.2014.04.001. 